\title{
Characterization of the leakage problem in Salhab earthen dam using electrical resistivity tomography and SP measurements, Syria
}

\author{
Walid AL-FARES \\ Atomic Energy Commission of Syria, Department of geology, \\ P.O. Box 6091, Damascus, Syria \\ e-mail: cscientific@aec.org.sy, tel.: +963-11-2132580, fax: +963-11-6112289
}

\begin{abstract}
The earthen dam of Salhab is located in the southern margins of Al-Ghab plain at $3-4 \mathrm{~km}$ of Salhab town northern-west of Syria. The dam consists of two separated embankments: the main one extends east-west along a distance of $895 \mathrm{~m}$ with $14.5 \mathrm{~m}$ height, while the second embankment towards northwest-southeast over a distance of $510 \mathrm{~m}$ and $11 \mathrm{~m}$ of height. The dam crest has a constant topographic elevation of $220 \mathrm{~m}$ above sea level (a.s.l). Electrical Resistivity Tomography surveys (ERT) combined with a Self-Potential measurements (SP), were implemented at the upstream and at the top of the main and the secondary embankments of the dam in order to identify the possible leakage zones under the dam's body. The interpretation of the ERT sections and the SP measurements, carried out at the upstream side, revealed a distinct zone of leakage extending along the beginning and the end parts under the main embankment. Moreover, many punctual anomalous spots of low resistivity values were recognized within the dam's clay core. One of those spots was confirmed by the implementation of a detailed ERT profile and by a piezometric borehole drilled at the top of the dam. Whereas, the clay core of the secondary embankment seems relatively coherent and homogeneous as well as a trace of a tectonic fault was identified under the end part of the embankment body but no manifestations of leakage were observed under and behind the secondary dam body.
\end{abstract}

Key words: ERT and SP surveys, leakage, Salhab earthen dam, Syria

\section{Introduction}

Leakage issue is a common problem and widely happens in the earth fill dams either through its foundations or through the dam body itself. The Subsurface geological structure and tectonic features are the most factors leading to the occurrence of leakage processes form dams (Johansson and Dahlin, 1996; Panthulu et al., 2001; Foster et al., 2002; Al-Fares, 2014; Bedrosian et al., 2012). The evolution of leakage problem within or under 
the dam body leads to increasing the leaking rate and affects directly on the safety and stability of the dam (Sjödahl et al., 2006; Asfahani et al., 2010; Bedrosian et al., 2012). Therefore, it is necessary to conduct periodic monitoring for the leakage rates to avoid the occurrence of a sudden failure or collapse of the dam. Using modern and sophisticated geophysical techniques contributes significantly in giving an image of the subsurface geological features and consequently outlining the possible paths of water leakage (Seaton and Burbey, 2002; Cho and Yeom, 2007; Al-Fares, 2011; Ikard et al., 2013; Gutiérrez et al., 2015). This certainly assists in providing appropriate technical solutions to reduce the leaking rates and ensure the safety and stability of the dam.

The Salhab earthen dam is located in north-west of Syria at the southern Al-Ghab plain margins north-west Hama city (Fig. 1). The dam consists of two embankments: the main one extends east-west and has a length of $895 \mathrm{~m}$, and it has $14.5 \mathrm{~m}$ of height, while the second towards northwestsoutheast with the length of $510 \mathrm{~m}$ and $11 \mathrm{~m}$ of height. The both dam's embankments have a constant topographic level of $220 \mathrm{~m}$ above sea level
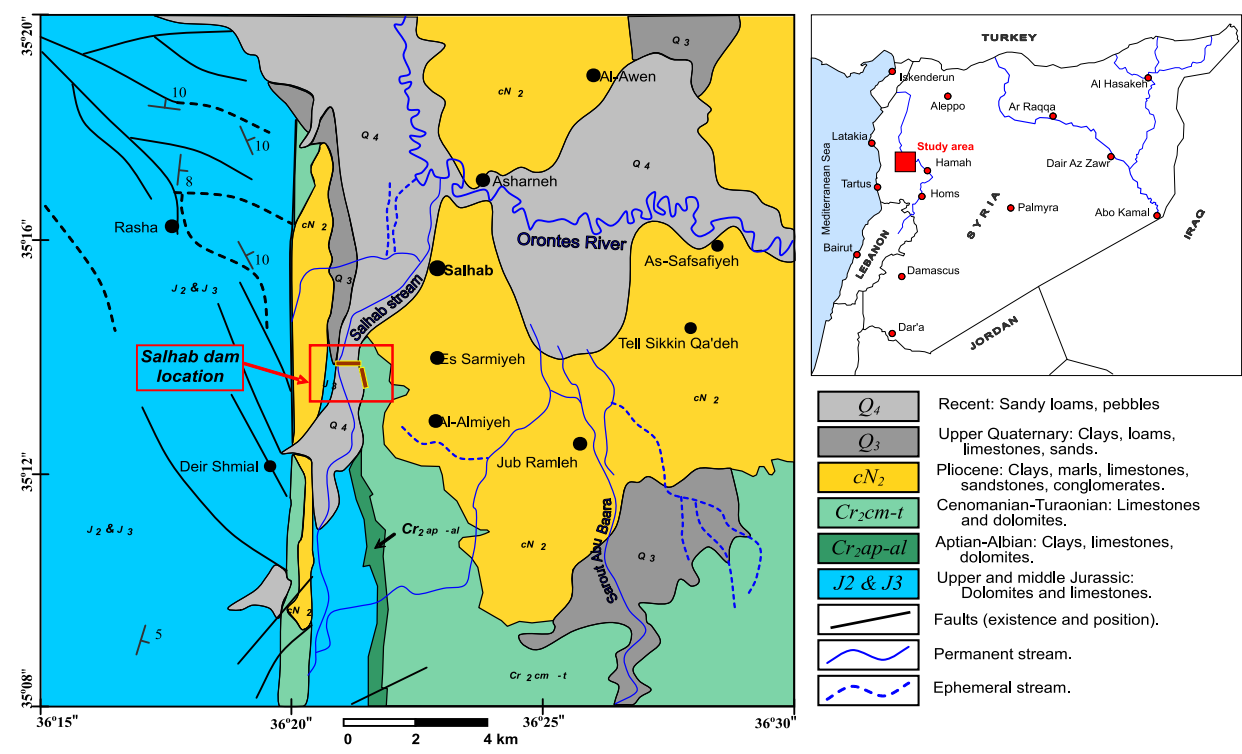

Fig. 1. Simplified geological map of the study area showing the location of Salhab dam (modified after Ponikarov, 1963). 
(Fig. 2). The dam's lake has a surface of the 145 hectares with $2 \mathrm{~km}$ of length and $7.75 \mathrm{Mm}^{3}$ as a storage capacity. The dam was built on Salhab riverbed in 1993 in order to fend off the floods on Al-Ghab plain and to storage the water for agricultural uses in summer. Most of the water of reservoir comes from the flows of the karstic springs scattered on the slopes of the mountain heights located at the west and south of the dam site and close to Deir Shamil village. After putting the dam in operation for the first time, a water flow was observed exiting from the piezometric wells drilled behind the main embankment body and the amount of the percolated water through the leaching channel reached up to $160 \mathrm{~L} / \mathrm{s}$, especially when the storage level passes $210 \mathrm{~m}$ (Al-Diab, 2008). This phenomenon is continuing and repeated during the consecutive storage periods. In the current case study, the Electrical Resistivity Tomography (ERT) method and SP measurements were proposed to contribute in outlining the possible zones of water leakage through the implantation of many geo-electrical profiles close and along the dam body. Since this technique has provided its performance in giving a clear image of the substructure and localizing the probable leaks paths in many earthen dams studies (Oh and Sun, 2008; Osazuwa and Chii, 2009; Moore et al., 2011; Thompson et al., 2012).

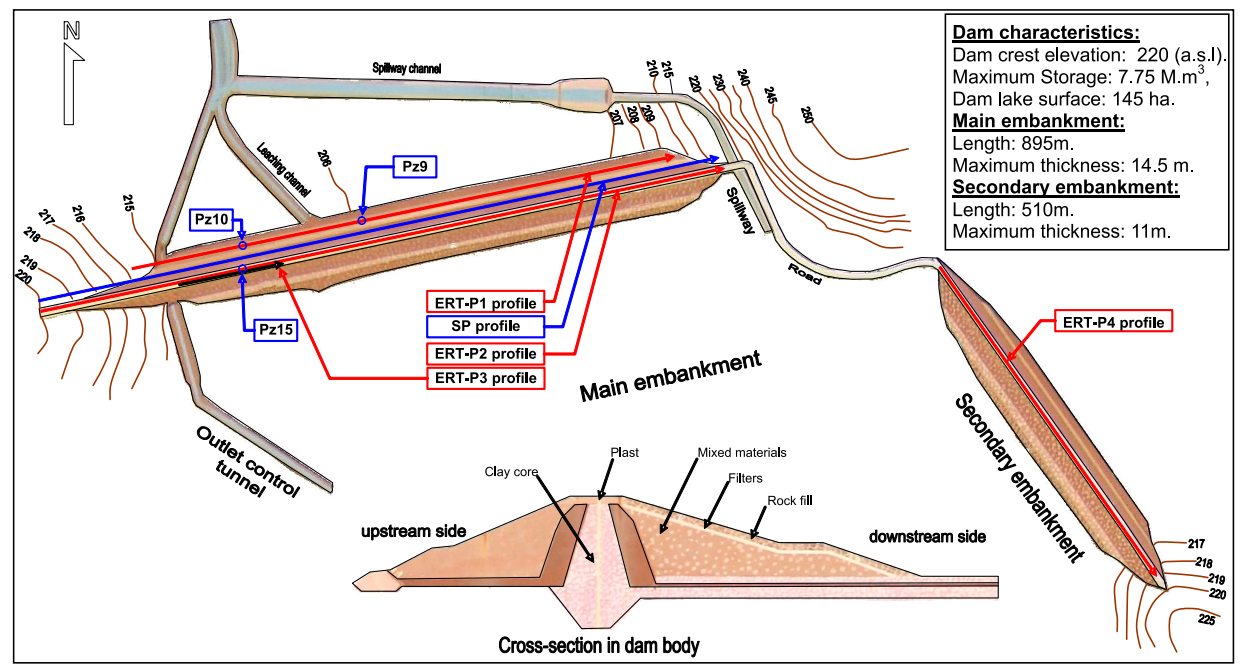

Fig. 2. Shows the general structure of Salhab dam, and the locations of the ERT, SP profiles and $\mathrm{Pz}$ piezometric boreholes. 
Therefore, the aim of the present case study is to identify the potential zones of leakage in the dam through mapping in detail the subsurface structures of the geological formations underneath and behind the dam body by the implementation of numbers of electrical resistivity tomography profiles combined with SP measurements and available boreholes logs data.

\section{Geological and hydrogeological settings}

Salhab dam is located at the southern fringes of Al-Ghab plain depression (Fig. 1). The region including the dam area is strongly influenced by the tectonic activities of the Dead Sea Faults Systems (DSFS) of the large Asian-African Rift (Devyatkin et al., 1997; Brew, 2001). The central parts of Al-Ghab depression are filled by Neogene and Quaternary alluvium deposits with thickness reaching more than $100 \mathrm{~m}$. These deposits are overlaying uncomfortably the Cretaceous calcareous rocks, which constitute basement of the Al-Ghab basin (Ponikarov, 1963; Gomez et al., 2006). From a local geological perspective, the mountains located to the west of Salhab dam consist of fractured and karstified limestones and dolomites rocks of Upper and Middle Jurassic $\left(\mathrm{J}_{3}, \mathrm{~J}_{2}\right)$. While the heights located at the East of the dam are compounded by limestones and dolomites rocks of Cenomanian-Turonian $\left(\mathrm{Cr}_{2} \mathrm{~cm}-\mathrm{t}\right)$. These rocks are outcropping over formations of limestones and dolomites, alternating with marly and chalky limestones of Aptian and Albian formation ( $\mathrm{Cr}_{1}$ ap-al).

With regard to the dam site, the preliminary investigations and the geological maps 1/200,000 and 1/50,000 (Ponikarov, 1963; General Establishment for Geology and Mineral Resources, 1984) indicate that the storage basin of the dam, close to the axe of the main embankment, is covered by Quaternary alluvial deposits compounded essentially from clays, loams, sands and pebbles $\left(\mathrm{Q}_{4}\right)$. These deposits overlay a geological formation consisting of marls, limestones, sandstones and consolidated conglomerates referred to the upper Miocene and Pliocene $\left(\mathrm{cN}_{2}\right)$. The conglomerates are composed of rounded to sub-angular pebbles and boulders in limy cement, whereas, the alluvial deposits, close to the secondary embankment, cover a layer composed of marly calcareous rocks. The difference in the geological structure of the storage basin close to the main and secondary embankments of the dam is due to the presence of a tectonic fault on the left shoulder 
of the dam extending parallel to the main course of the dam valley. This fault led to the decline of the level of the storage basin and the rise of the Cretaceous plateaus chain in the east and played later an important role in determining the current course of the Salhab stream.

From hydrogeology point of view, the Quaternary alluvium deposits, which are composed from clays, sands and gravels, constitute the shallow groundwater aquifer in the study area. According to the hydrogeological investigations carried out in the site, the groundwater level appears at a depth ranging between $12-15 \mathrm{~m}$, nearby the main embankment, while it is about $24 \mathrm{~m}$ close to the second embankment. Whereas the limestone and dolomite formations referred to the Jurassic and Cretaceous ages, constitute the main and the deep aquifer in the region. These formations are characterized by high permeability due to the presence of cracks, fractures and karstic voids at various depths. The limestone and dolomite rocks are considered the main source of all of the karstic springs feeding the local rivers and streams in the region. In general, the groundwater flow directs from West to East perpendicular to water flow of Salhab river.

\section{Methodology and instruments}

\subsection{ERT measurements}

The electrical resistivity tomography (ERT) was applied in Salhab earthen dam to identify the origin of the leakage observed behind the dam body while the dam is partially filled with water. For this purpose, three ERT profiles (ERT-P1, ERT-P2, and ERT-P3) of different lengths have been conducted in upstream and at the top of the main embankment (Figs. 2 and 3). Only one ERT profile (ERT-P4) was carried out at the top of the secondary embankment. The ERT profiles were straight and parallel to the dam body and realized at water storage level of $215 \mathrm{~m}$ (a.s.l.).

To execute the field measurements, the resisto-meter Syscal Switch-72 was used. The instrument is equipped with a control unit and four multiswatches cable bobbins to connect 72 electrodes at once with maximum inter-electrodes step of $5 \mathrm{~m}$. The 72 electrodes are planted in a straight line along the measurement profile. Electrodes checking and the data collecting are performed automatically according to a mathematical sequence prepared 
in advance using special software. Each standard sequence of $360 \mathrm{~m}$ length includes 759 measuring points distributed on 16 levels of depth. In the case where the profile is longer than the standard sequence (up of $360 \mathrm{~m}$ ), a roll-along sequence or more are required to end the profile of the measurements. The roll-along sequence should be compatible with the standard one in term of configuration and the electrodes interval. The roll-along sequence used includes 304 additional measuring points. The collected data are au-

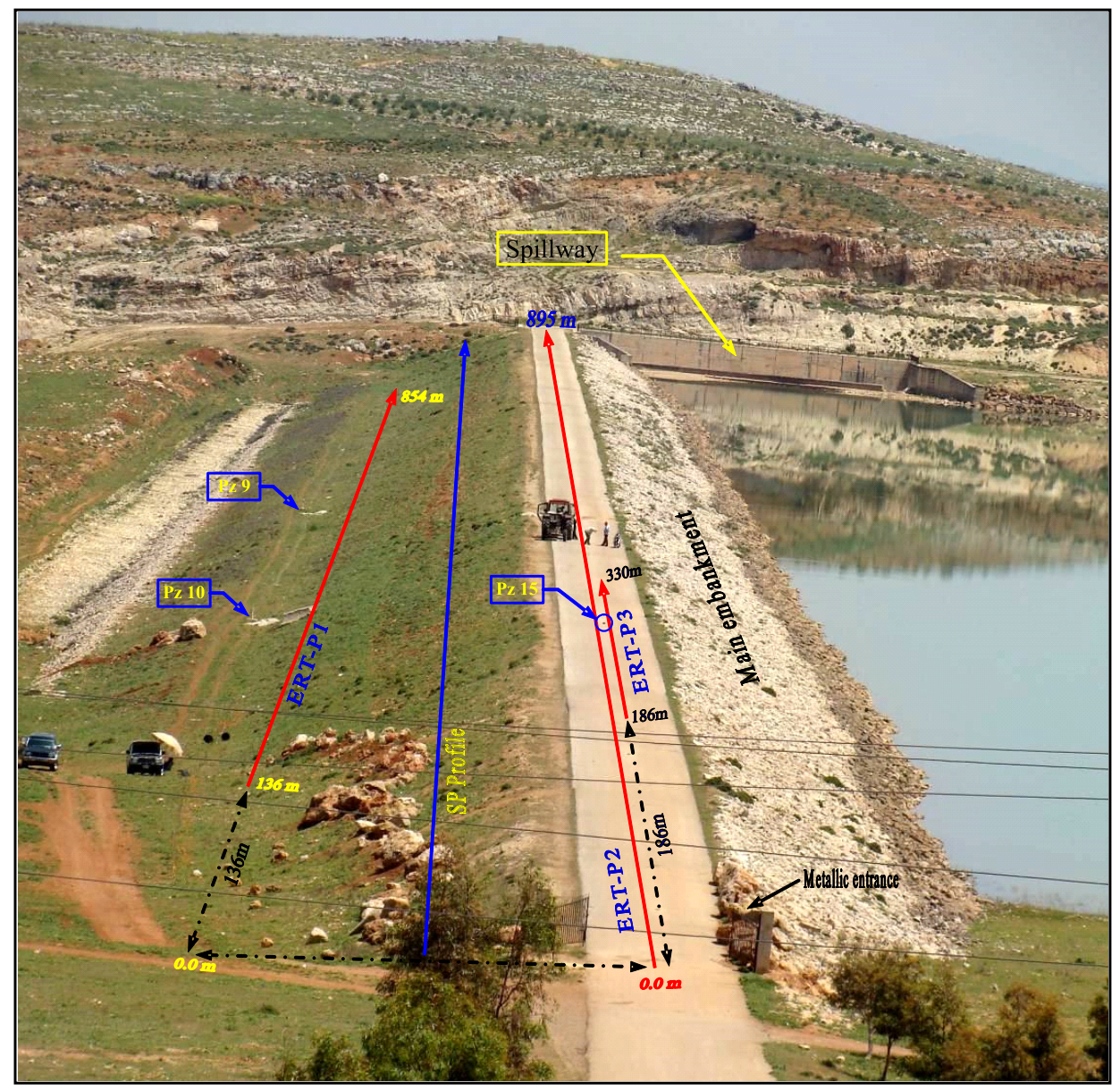

Fig. 3. View for arrangement of the ERT and SP profiles carried out in Salhab dam, and the locations of the piezometric boreholes Pz9, Pz10 and Pz15. 
tomatically stored in the instrument's memory using Schlumberger-Wenner sequence with an inter-electrode spacing of 2 or $5 \mathrm{~m}$.

\subsection{SP measurements}

Within the framework of this work, a team from the Directorate General of Water Resources of Damascus, implemented the field SP measurement simultaneously with the ERT surveys (Omer and Habashiya, 2008). The resisto-meter SAS-300 (Sudesh made) equipped by non-polarized electrodes was used to carry the SP measurements. To perform the field measurements, the non-polarized electrodes are filled with copper sulfate solution where one electrode remains fixed in a certain point and the other electrode is moved according to a constant measurement step every $5 \mathrm{~m}$. More than 10 $\mathrm{SP}$ profiles were executed in upstream side of the main and the secondary embankments and the lake shoulders. The SP profile marked in the Figs. 2 and 3 was the closer to the ERT-P2 profile; therefore the two profiles were interpreted together.

\section{Results and discussion}

In order to interpret the ERT profiles, the raw data stored in the resistometer memory were transported to a PC and inverted using RES2DINV program developed by Loke and Barker (1996). The ERT data were inverted using the least-squares method including smoothing of model resistivity to get better results. This method depends on reducing the differences between the measured and calculated apparent resistivity values. The inverse model resistivity section represents the true resistivity values of the subsurface geological formations.

\subsection{ERT-P1 profile}

This profile is carried out on the terrace of the main embankment backside, which has a steady topographic level of $212 \mathrm{~m}$ (Fig. 3). This profile starts at the point $136 \mathrm{~m}$ from the metallic entrance of the dam. The dam entrance was considered as a reference start point for all of the ERT profile 
implemented at the main embankment. This profile was carried out with $2 \mathrm{~m}$ inter-electrode spacing and extends along a distance of $718 \mathrm{~m}$. The Fig. 4 shows the geo-electrical inverted section of the ERT-P1 profile where a surface layer extending horizontally along the profile section can be distinguished. The thickness of this layer ranges between 0 and $5 \mathrm{~m}$ and it increases toward the end of the geo-electrical section. The resistivity values of this layer vary between $15-30 \Omega \mathrm{m}$, most likely related to the main components of the embankment terrace, which is composed of a mixture of sandy clays and some gravels. Structurally, this layer seems homogenous and no anomalous features can be noted.

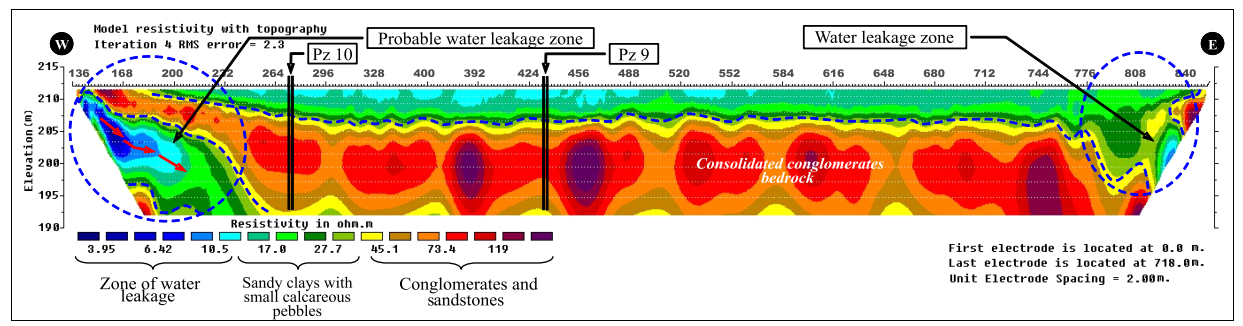

Fig. 4. Interpretation of the ERT-P1 profile carried out on the upstream terrace of the main embankment of Salhab dam, Pz9 and Pz10 are piezometric boreholes.

Underlying, a notable and geometric homogenous thick layer, parallel to the previous terrace, can be mapped. This layer structurally seems to be uniform over all the profile except at the two edges. It is almost related to the consolidated conglomerate and sandstone formation referred to it in the geological setting. This formation could be considered as the main compact bedrock in the basin of the dam lake. The thickness of this formation reaches more than $15 \mathrm{~m}$ and the resistivity values ranging between $40-150 \Omega \mathrm{m}$. The available real data, derived from the piezometric boreholes logs Pz10 and $\mathrm{Pz}$, which are implanted on the terrace behind the dam body, confirms this finding (Figs. 4 and 5). Moreover, an up normal blue zone is observed at the beginning of the ERT-P1 section. This zone has a limited shape and it seems to be perched under the beginning of indicated previous bedrock layer. The observed zone is characterized by low resistivity values ranging between 4$10 \Omega \mathrm{m}$. These low values could be influenced either by a groundwater flow coming from the neighbouring mountainous western slopes towards the dam area or it could be a result of leakage process from the dam's lake especially 

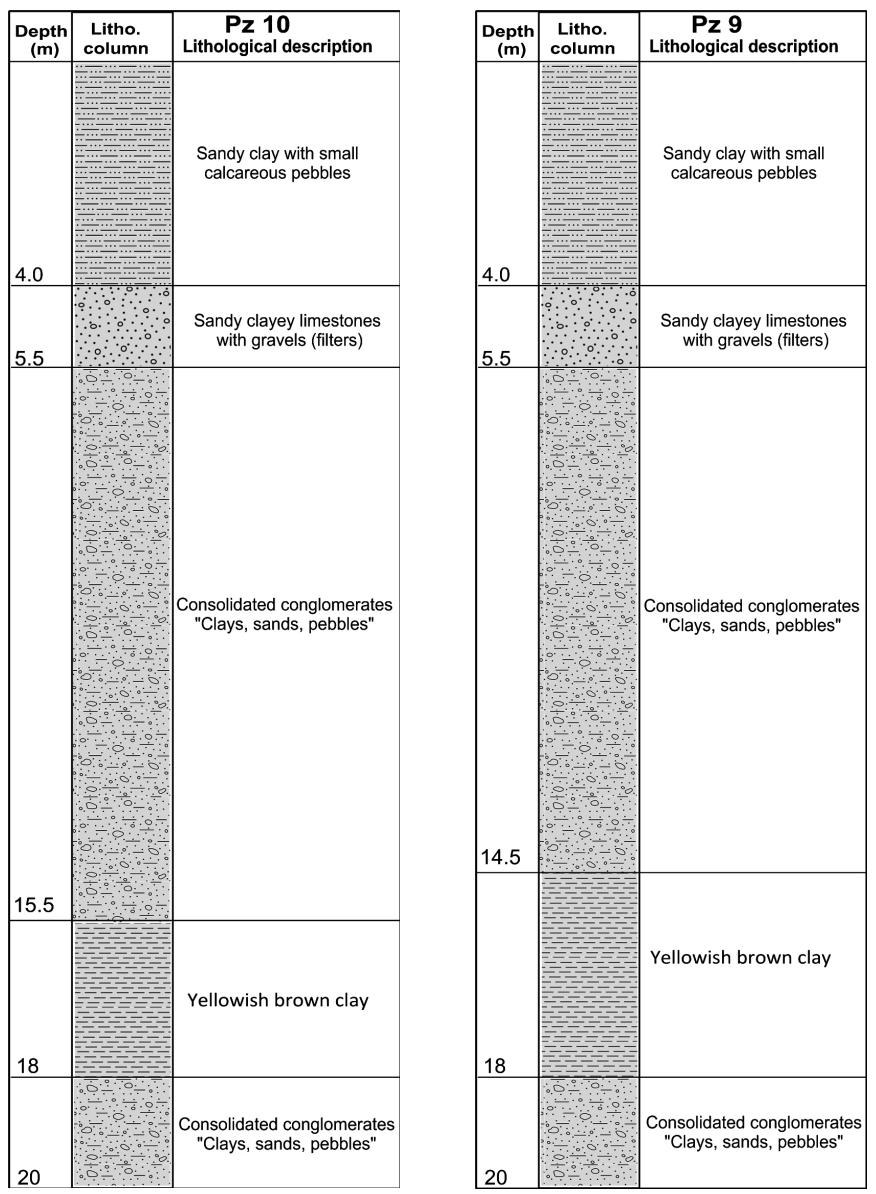

Fig. 5. The piezometric borehole logs of the Pz10 and Pz9 drilled on the terrace of the main embankment backside (modified after the General Company for Water Studies, 2008).

when the water storage level starts rising. Another structural anomaly is also identified at the end part of the geo-electrical section between the distance of 770 and $830 \mathrm{~m}$, where a discontinuity feature can be traced at the end of the bedrock layer. This feature is situated opposite to the dam's flooding channel (spillway) and could constitute a possible flow path for water via the contact zone between the embankment body and adjacent rocks formation. 


\subsection{ERT-P2 profile}

This profile is performed along the crest of the main embankment and it extends along a distance of $895 \mathrm{~m}$ long, with constant topographic elevation of $220 \mathrm{~m}$ above sea level (Fig. 3). In order to carry out this profile on the top of the dam, the hard asphaltic layer was punctured every $5 \mathrm{~m}$ using an electrical driller to facilitate the plantation of the electrodes. In this case, the investigation depth of the used configuration is about $50 \mathrm{~m}$. The implanted electrodes were wetted with water and some clay added to ensure the contact with the ground and to reduce the perturbation resulting from the electrodes effect. The Fig. 6 shows the interpretation of the inverted geo-electrical section of the ERT-P2 profile. The blue doted straight line represents the water level in the lake through the measurements, while the red dotted line represents the boundaries of the dam body (clay core) with the natural land surface in the lake. According to the ERT-P2 section, a blue zone of low resistivity values (less than $20 \Omega \mathrm{m}$ ) is appeared in the left part of the section and extends along the first $300 \mathrm{~m}$ beneath the boundaries of the dam body. The presences of this zone again in this section enhance what was observed in the previous profile. On other hand, the results obtained from the interpretation of the SP measurements which is carried out at the slope of main embankment backside, confirm the presence of this leakage zone. The Fig. 7 shows the compatibility between the results of the interpretation of SP and ERT-P2 section, where an anomaly of negative SP values (less than $-40 \mathrm{mV}$ ) can be noted along the first $350 \mathrm{~m}$ of the two profiles which corresponds to the blue zone of the low resistivity mentioned above. This finding enhances again the possibility of the occurrence of the leakage processes through this sector and cause a flow of water from the piezometric boreholes drilled behind the dam particularly when the storage level rises.

The specified range of the red dotted line outlines the boundaries of the clay core of the main embankment (Fig. 5). Where, the resistivity values are ranging between 30 and $60 \Omega \mathrm{m}$. Several separated small zones of low resistivity values, can be observed within the clay core at several distances 300, 480, 640, and $840 \mathrm{~m}$ along the ERT-P2 section. All of these zones are located between the 200 and $210 \mathrm{~m}$ topographic levels. The existence of such abnormal areas could be affected by the occurrence of some leaking or filtration processes through the clay core leading to wetting some parts 


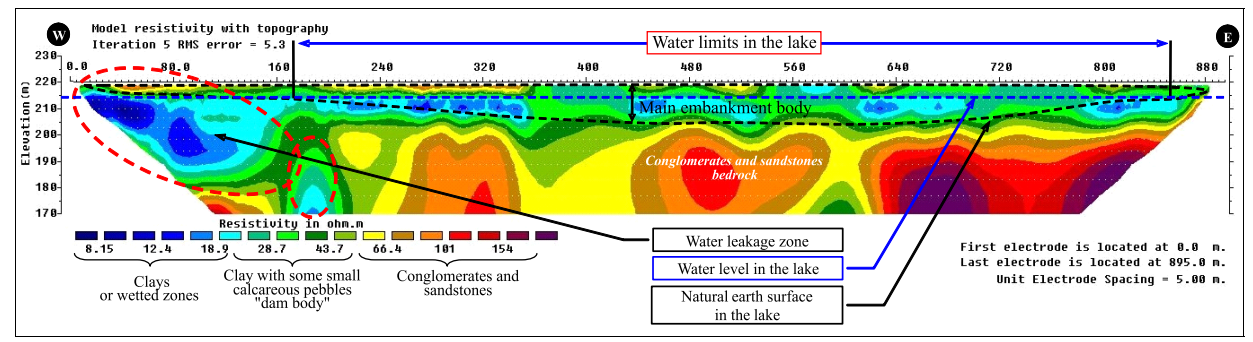

Fig. 6. Interpretation of the ERT-P2 profile carried out along the crest of the main embankment of Salhab dam.

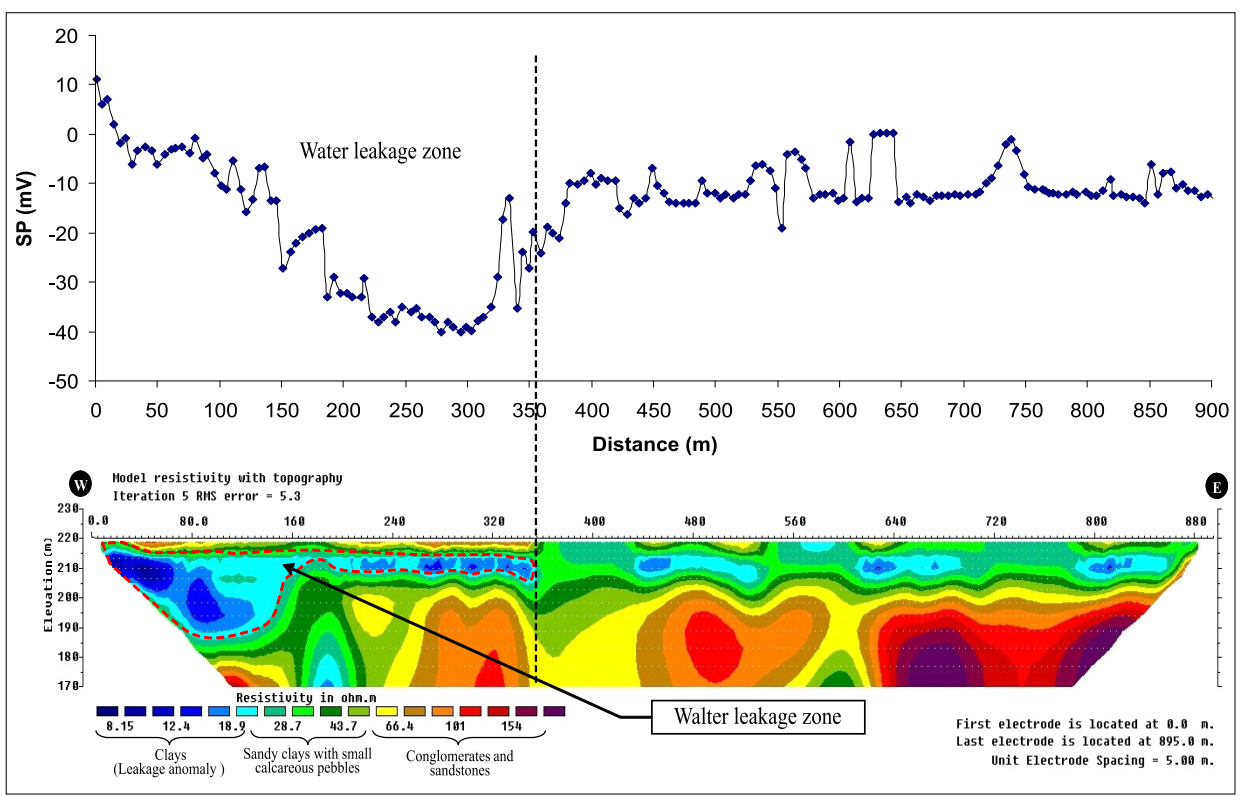

Fig. 7. Illustrates the compatibly between the results of the ERT section and the SP measurements carried out at the main embankment of Salhab dam.

inside the dam body. Therefore, to confirm the presence of such these filtration zones and to explain the appearance of water in the piezometric borehole Pz15, a short detail ERT profile was carried out at the top of the embankment adjacent to Pz15, this will be discussed later through the interpretation of ERT-P3 profile. 
Just below the main embankment of the dam, a somewhat heterogeneous layer appears. This layer is expressed by resistivity values ranging between 70 and $200 \Omega \mathrm{m}$. The heterogeneity in this layer could be due to the presence of consolidated conglomerates in some parts, accompanied with clay, sandstone and marl in other parts. The thickness of this layer exceeds more than $30 \mathrm{~m}$ forming the main bedrock beneath the dam body.

\subsection{ERT-P3 profile}

This profile is carried out on the top of the main embankment in order to clarify the presence of the water in the piezometer Pz15. The start point of this profile is located at $186 \mathrm{~m}$ from metallic dam entrance (Fig. 3). This profile extends along a distance of $144 \mathrm{~m}$ with $2 \mathrm{~m}$ as inter-electrodes spacing. The Fig. 8 illustrates the geo-electrical section of the ERT-P3 profile. A thin surface layer of 1-1.5 m thickness can be distinguished, this layer represents the plast layer which is composed of sands and gravel protected by a thin asphaltic sheet covering the top of the embankment. The resistivity of this layer reaches more than $220 \Omega \mathrm{m}$.

The rest of the ERT section represents the clay core of the embankment body, where two geo-electrical layers can be outlighting: the first one extends alone all the section and has a thickness $5 \mathrm{~m}$ (net blue colour) and it is confined between the levels 212 and $217 \mathrm{~m}$. This layer is relatively characterized by low resistivity values varying between $12-20 \Omega \mathrm{m}$ and seems to be uniform and homogenous. While, the layer below, represents the lower part

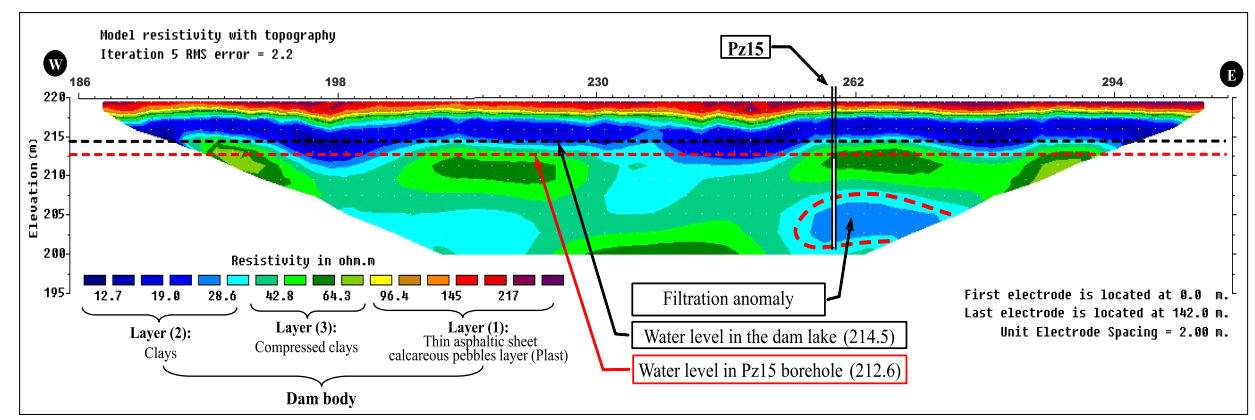

Fig. 8. Interpretation of the ERT-P3 profile carried out at the top of the main embankment, which is passed by the Pz15 borehole. 
of the clay core which shows a slight increase in the resistivity values varying between $30-75 \Omega \mathrm{m}$. The increasing in the resistivity values may possibly be attributed to the changing of the nature of the clay core components or it could be related to dynamic factors such as the compression applied on the clayey landfills through the construction of the dam body. On the other hand, an anomaly of low resistivity is appeared as a blue spot at the base and around the piezometric borehole Pz15 base (Fig. 8). This may explicate the presence of water inside the borehole, which could be almost related to the existence of a fable filtration in this part of the dam body. It is also worth mentioned that through the drilling of Pz15 borehole, it was noted that the drilling process was easy and fast within the depths from 16 and $17.5 \mathrm{~m} \mathrm{(20} \mathrm{m} \mathrm{is} \mathrm{the} \mathrm{depth} \mathrm{of} \mathrm{the} \mathrm{Pz15)} \mathrm{and} \mathrm{the} \mathrm{samples'} \mathrm{yield} \mathrm{was} \mathrm{less} \mathrm{than}$ $50 \%$. This enhances again the occurrence of filtration or leakage at the toe of the dam (Fig. 9). Consequently, the presence of filtration zones or leakage within the clay core body could pose problems on the stability and the safety of the dam in the future. Therefore, a permanent monitoring program is required to ensure the safety of dam particularly at high water storage levels.

\subsection{ERT-P4 profile}

This profile was implemented at the top of the secondary embankment body and extends along a distance of $535 \mathrm{~m}$ which is the length of the secondary embankment (Fig. 2). The geo-electrical section of the ERT-P4 profile is shown in the Fig. 10. The red dotted line represents the lower boundary of the embankment with the natural ground surface in the lake. The embankment body (net blue colour) seems to be clear and homogeneous, and the resistivity values ranges between 20 and $60 \Omega \mathrm{m}$ and the thickness is about 10-12 m. The embankment overlays over a layer more resistant, where the resistivity values vary between 200 to $500 \Omega \mathrm{m}$ with a thickness reaches more than $30 \mathrm{~m}$. The upper parts of this layer are linked to the alluvial deposits, which are compound of clay, sands and gravels. Whereas, the lower parts of this layer could be associated to the marl and chalky calcareous rocks, which form the bedrock of the secondary embankment of dam depending on the investigations and the geological setting. With regard to the last part of the geo-electrical section, the formations become more resistant and the 


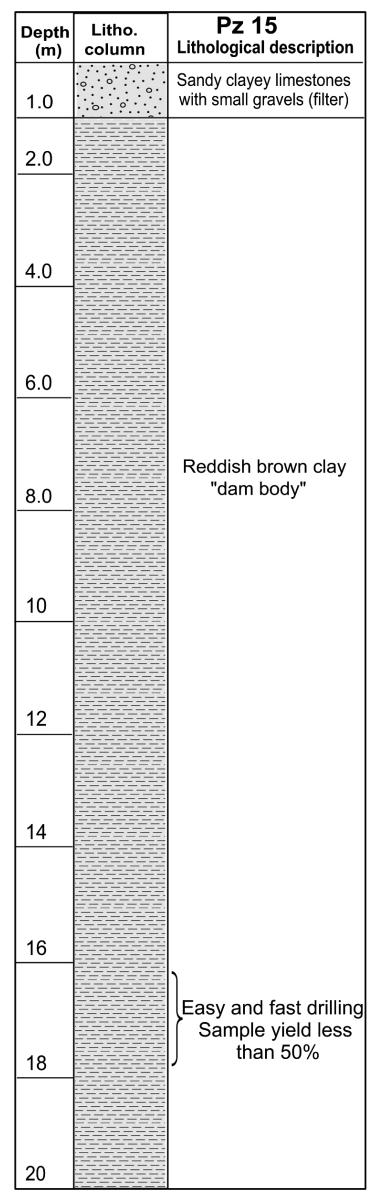

Fig. 9. The piezometric borehole log of Pz15 drilled on the top of the main embankment, which indicates to ease and speed in drilling within the depth 16-17.5 m (modified after the General Company for Water Studies, 2008).

resistively reaches more than $2000 \Omega \mathrm{m}$. The high resistivity values are associated with the hard limestone and dolomite rocks, which form the nearby mountain slopes.

The contrast in the resistivity values at the last part of the section (at the distance $400 \mathrm{~m}$ of the profile), indicate to the existence of the fault, which separates the marly and chalky limestone formation $(200-500 \Omega \mathrm{m})$ and the hard calcareous rocks $(2000 \Omega \mathrm{m})$. The trace of this fault is clear in 
the attached photo with the ERT section of the profile ERT-P4 (Fig. 10). On the other hand, the difference in the nature of the bedrock of the main embankment (sands and conglomerates) and the secondary embankment (marly and chalky limestone), confirms the presence of this fault on the right shoulder of the lake parallel to the actual main course of Salhab's river.
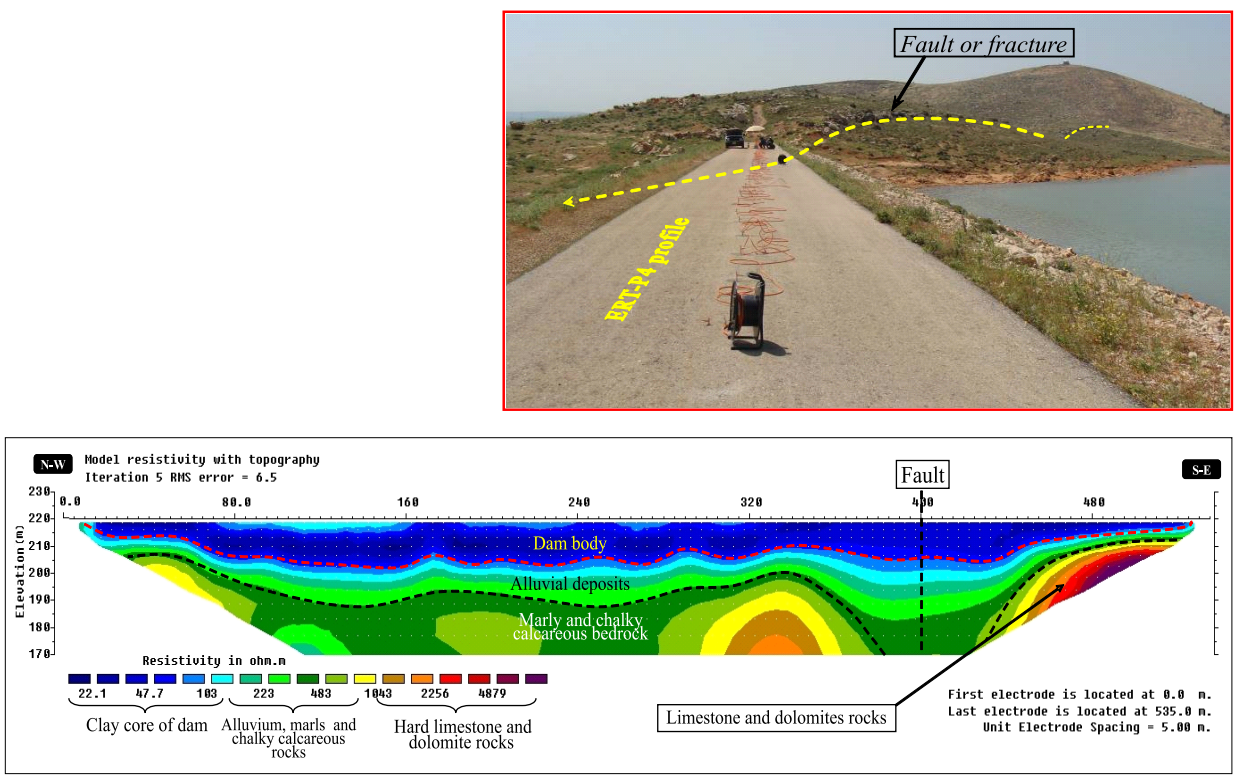

Fig. 10. Interpretation of the ERT profile P4 section carried out at the top of the secondary embankment of Salhab dam, the above photo shows the trace of the detected tectonic fault at the adjacent geological formations to dam body.

\section{Conclusion}

The interpretation of the Electrical Resistivity Tomography (ERT) sections carried out in Salhab earthen dam confirmed the differences in the subsurface geological structure under the main and secondary embankment bedrocks of the dam, which is due to the effect of a tectonic fault hits the right shoulder of the dam lake.

The interpretation of the ERT section of the profile performed behind the main dam's body revealed two possible leakage zones at the beginning 
and end of the profile close to the spillway channel. Whereas, the interpretation of the section ERT profile and the SP measurements carried out at the top and backside of the main embankment, revealed a zone of low resistivity values, extends alone the $350 \mathrm{~m}$ distance of the section. This zone includes many probable punctual spots of leakage or filtration, one of these filtration spots explains the presence of water in the piezometric borehole (Pz15) drilled at the top of the dam.

With respect to the ERT section carried out on the top of the secondary embankment, the embankment appears to be homogeneous and impermeable, and the subsurface bedrock does not show any manifestations of leakage or filtration at least within the available investigation depth.

Consequently, it is believed that most of the leakage or outflow processes in Salhab earthen dam occur through the bedrock under the two edges of the main embankment of the dam as well as through the area close to the spillway channel.

Acknowledgements. The author would like to express his thanks and gratitude to Professor I. Othman, Director General of the atomic energy commission of Syria (AECS) for his encouragement and constant support. Thanks are also due to the colleagues in the department of geology for their helps. We gratefully acknowledge the anonymous reviewers for their important comments and suggestions that considerably enhanced the quality of the manuscript.

\section{References}

Al-Diab S., 2008: Report of the geophysical investigations executed under the technical conditions proposed by French EDF company to estimate the technical situation of Salhab dam, 44 pp. (internal report).

Al-Fares W., 2014: Application of electrical resistivity tomography technique for characterizing the leakage problem in Abu Baara earth dam, Syria. Int. J. Geophys., Article ID 368128, 9 p., doi : 10.1155/2014/368128.

Al-Fares W., 2011: Contribution of the geophysical methods in characterizing the water leakage in Afamia B dam, Syria. J. Appl. Geophys., 75, 3, 464-471, doi: 10.1016/ j.jappgeo.2011.07.014.

Asfahani J., Radwan Y., Layyous I., 2010: Integrated geophysical and morphotectonic survey of the impact of extensional tectonics on the Qastoon dam, Northwestern Syria. Pure Appl. Geophys., 167, 3, 323-338, doi: 10.1007/s00024-009-0019-y. 
Bedrosian P. A., Burton B. L., Powers M. H., Minsley B. J., Phillips J. D., Hunter L. E., 2012: Geophysical investigations of geology and structure at the Martis Creek Dam, Truckee, California. J. Appl. Geophys., 77, 7-20, doi: 10.1016/j.jappgeo. 2011. 11.002 .

Brew G. E., 2001: Tectonic evolution of Syria interpreted from integrated geophysical and geological analysis. Ph.D. dissertation at Cornell University, USA, $322 \mathrm{pp}$.

Cho I.-K., Yeom J.-Y., 2007: Crossline resistivity tomography for the delineation of anomalous seepage pathways in an embankment dam. Geophysics, 72, 2, 31-38, doi: $10.1190 / 1.2435200$.

Devyatkin E. V., Dodonov A. E., Sharkov E. V., Zykin V. S., Simakova A. N., Khatib K., Nseir H., 1997: The El-Ghab rift depression in Syria: its structure, stratigraphy, and history of development. Stratigr. Geol. Correl., 5, 4, 362-374.

Foster M. A., Fell R., Davidson R., Wan C. F., 2002: Estimation of the probability of failure of embankment dams by internal erosion and piping using event tree methods. ANCOLD Bulletin, 121, 75-82.

General Company for Water Studies, 2008: Directorate of Investigation, Department of Engineering Geology, Salhab Dam Project 2008, Homs, Syria.

General Establishment for Geology and Mineral Resources, 1984: The geological map of Syria, Misyaf sheet scale 1:50,000. Ministry of Petroleum and Mineral Resources, Damascus, Syria.

Gomez F., Khawlie M., Tabet C., Darkal A. N., Khair K., Barazangi M., 2006: Late Cenozoic uplift along the northern Dead Sea transform in Lebanon and Syria. Earth Planet. Sci. Lett., 241, 3-4, 913-931, doi : 10.1016/j.eps1.2005.10.029.

Gutiérrez F., Mozafari M., Carbonel D., Gómez R., Raeisi E., 2015: Leakage problems in dams built on evaporites. The case of La Loteta Dam (NE Spain), a reservoir in a large karstic depression generated by interstratal salt dissolution. Eng. Geol., 185, 139-154, doi: 10.1016/j.enggeo.2014.12.009.

Ikard S. J., Revil A., Schmutz M., Karaoulis M., Jardani A., Mooney M., 2013: Characterization of focused seepage through an earthfill dam using geoelectrical methods. Ground Water, 52, 6, 952-965 doi: 10.1111/gwat.12151.

Johansson S., Dahlin T., 1996: Seepage monitoring in an earth dam by repeated resistivity measurements. Eur. J. Environ. Eng. Geophys., 1, 3, 229-247.

Loke M. H., Barker R. D., 1996: Rapid least-square inversion of apparent resistivity pseudo-section by a quasi-Newton method. Geophys. Prospect., 44, 1, 131-152, doi: $10.1111 / j .1365-2478.1996 . t b 00142 . x$.

Moore J. R., Boleve A., Sanders J. W., Glaser S. D., 2011: Self-potential investigation of moraine dam seepage. J. Appl. Geophys., 74, 277-286, doi: 10.1016/j.jappgeo. 2011.06 .014$.

Oh S., Sun C. G., 2008: Combined analysis of electrical resistivity and geotechnical SPT blow counts for the safety assessment of fill dam. Environ. Geol., 54, 1, 31-42, doi: $10.1007 / \mathrm{s} 00254-007-0790-y$.

Omer Kh., Habshiya M., 2008: The geophysical investigations carried out in Salhab dam. General Water Resources Directorate in Damascus (internal report). 
Osazuwa I. B., Chii C. E., 2009: A two-dimensional electrical resistivity imaging of an earth dam, Zaria, Nigeria. J. Environ. Hydrol., 17, 28, 1-8.

Panthulu T. V., Krishnaiah C., Shirke J. M., 2001: Detection of seepage paths in earth dams using self-potential and electrical resistivity methods. Eng. Geol., 59, 3-4, 281-295, doi: 10.1016/S0013-7952(00)00082-X.

Ponikarov V., 1963: The geological map of Syria, Hama-Latheqieh sheet, scale 1:1200,000, V.O. Technoexport. Ministry of Industry, Damascus, Syria.

Seaton W. J., Burbey T. J., 2002: Evaluation of two-dimensional resistivity methods in a fractured crystalline-rock terrain. J. Appl. Geophys., 51, 1, 21-41, doi: 10.1016/ S0926-9851 (02) 00212-4.

Sjödahl P., Dahlin T., Zhou B., 2006: 2.5D resistivity modeling of embankment dams to assess influence from geometry and material properties. Geophysics, $\mathbf{7 1}, 3,107-114$, doi : 10.1190/1.2198217.

Thompson S., Kulessa B., Luckman A., 2012: Integrated electrical resistivity tomography (ERT) and self-potential (SP) techniques for assessing hydrological processes within glacial lake moraine dams. J. Glaciol., 58, 211, 849-858, doi: 10.3189/2012JoG11 J235. 